\title{
LARYNGOLOGY
}

\section{Differential chemokine expression patterns in tonsillar disease}

\author{
Differenti pattern di espressione delle chemochine nella patologia tonsillare
}

\author{
M. Mandapathil'1,2, U. H.Beier ${ }^{3}$, H. Graefe ${ }^{1}$, B. Kröger, J. Hedderich5, S. Maune ${ }^{6}$, J. E Meyer ${ }^{1}$ \\ ${ }^{1}$ Department of Otorhinolaryngology, Head and Neck Surgery, Asklepios St. Georg, Hamburg, Germany; \\ ${ }^{2}$ Department of Otorhinolaryngology, Head and Neck Surgery, University of Marburg, Germany; ${ }^{3}$ Department of \\ Medicine, Perelman School of Medicine, University of Pennsylvania, PA, USA; ' Department of Otorhinolaryngology, \\ University of Bremen, Bremen, Germany; ${ }^{5}$ Institute of Medical Informatics and Statistics, University of Schleswig- \\ Holstein, Campus Kiel, Kiel, Germany; ${ }^{6}$ Department of Otorhinolaryngology, Head and Neck Surgery, Kliniken Köln, \\ Cologne, Germany
}

\section{SUMMARY}

Expression profiles of CXC- and CC-chemokines in various forms of tonsillar disease were studied to evaluate whether certain chemokines play a predominant role in a specific subset of tonsillar disease. Total RNA was isolated from 89 biopsies (21 hyperplastic palatine tonsils, 25 adenoids, 16 chronic inflammatory palatine tonsils and 27 chronic inflammatory palatine tonsils with histological prove of acute inflammation), reverse transcribed and subjected to PCR amplifying IL-8, Gro-alpha, eotaxin-1, eotaxin-2, MCP-3, MCP-4 and RANTES. 2\% agarose gel electrophoresis revealed a predominance of IL-8 in the chronic inflammatory palatine tonsil group compared to tonsillar hyperplasia. Furthermore, eotaxin-2 was strongly overexpressed in adenoid samples compared to chronic inflammatory specimens. Our data suggest that the majority of diseases related to adenoid formation are mediated via an eotaxin-2 expression, whereas chronic inflammatory tonsillitis is associated with IL-8 upregulation. These data imply that adenoids are related to a Th-2, and chronic inflammatory tonsillitis to a Th-1 based immune response.

KEY WORDS: Chemokines• Tonsillar disease • Eotaxin-2・Interleukin-8

\section{RIASSUNTO}

Sono stati valutati i profili di espressione delle chemochine CXC e CC in varie patologie tonsillari allo scopo di valutare quali specifiche chemochine abbiano un ruolo predominante nel determinare specifiche patologie tonsillari. L'RNA è stato isolato da 89 biopsie (21 tonsille palatine iperplastiche; 25 adenoidi; 16 tonsille con infiammazione cronica e 27 tonsille con infiammazione cronica e diagnosi istologica di infiammazione acuta), inversamente trascritto, e sottoposto ad amplificazione per IL-8, Gro-alpha, eotaxin-1, eotaxin-2, MCP-3, MCP-4 e RANTES. L'elettroforesi su gel di agarosio al $2 \%$ ha rivelato una predominanza di IL8 nel gruppo delle tonsille con infiammazione cronica rispetto al gruppo delle tonsille con iperplasia. Al contrario l'eotaxina 2 era fortemente iperespressa nel gruppo delle adenoidi, se comparata al gruppo con infiammazione cronica. I nostri dati suggeriscono che la maggior parte delle patologie correlate con la formazione delle adenoidi sono mediate dall' espressione di eotaxina 2, mentre la tonsillite cronica infiammatoria è associata all' iperespressione di IL8. Questi dati implicano che le adenoidi sono correlate ad una risposta immunitaria Th2, mentre la tonsillite infiammatoria cronica ad una risposta Thl.

PAROLE CHIAVE: Chemochine $\bullet$ Patologie tonsillari $\bullet$ Eotaxina-2 $\bullet$ Interleukina-8

Acta Otorhinolaryngol Ital 2018;38:316-322

\section{Introduction}

In 1884, Waldeyer first described an annular arrangement of lymphatic tissue at the entrance of the aerodigestive tract, which he suggested plays an important part in the host immune system, including the palatine tonsils, pharyngeal tonsil, lingual tonsils and tubal tonsils ${ }^{1}$. Especially the palatine as well as pharyngeal tonsils are known to play a key role in the development of the human host defense due to their location, histologic anatomy and functional capacities ${ }^{2}$. These structures harbour numerous different types of tissues, including epithelium, lymphoid follicles, blood vessels and connective tissues ${ }^{34}$. The combination 
of these different tissues as well as their anatomic arrangement in crypts facilitates optimised exposure and processing of antigens, which aid in evoking effective immune responses ${ }^{56}$. The palatine as well as the pharyngeal tonsils are secondary lymphoid organs and an integral part of the mucosa associated lymphatic tissue complex ${ }^{7}$. Multiplication, differentiation and stimulation of B-lymphocytes represent one of their major functions and are essential in processing the specific immune response ${ }^{8}$. B-lymphocytes constitute more than $50 \%$ of the tonsillar lymphocyte population, in contrast to the blood and other lymphoid organs ${ }^{910}$. The induction of the tonsillar-specific immune responses involves several distinct processes where chemokines play an integral role ${ }^{11-14}$. Chemokines are chemotactic cytokines, which can be classified into four subgroups depending on their arrangement of amino acids, namely CXC-, CC-, C- and $\mathrm{CX}_{3} \mathrm{C}$-chemokines ${ }^{15}{ }^{16}$. CXC-chemokines, like interleukin (IL)-8 and growth-regulated peptide - alpha (GRO-alpha), are responsible for chemotaxis of neutrophils, whereas CCchemokines, like eotaxin-1, eotaxin-2, monocyte chemotactic protein (MCP)-3, MCP-4, and RANTES (Regulated upon Activation, Normal $T$-cell Expressed and Secreted), promote the attraction of lymphocytes, monocytes, eosinophils and basophils ${ }^{17}$.

The presented work investigated the importance of different chemokines, i.e. IL-8, GRO-alpha, eotaxin-1, eotaxin-2, MCP-3, MCP-4 and RANTES in tonsillar inflammatory disease and tonsil hyperplasia.

\section{Materials and methods}

\section{Tissue samples}

This study included 89 patients who underwent surgery at the Department of Otorhinolaryngology, Head and Neck Surgery at the University of Schleswig-Holstein, Campus Kiel, Germany, for hyperplasia of either the palatine or pharyngeal tonsil, or chronic inflammation of the palatine tonsil, defined as recurrent acute tonsillitis over a period of $>6$ months. Samples were retrieved during surgery after written patient consent was obtained, in accordance with the ethical commission of the Christian-Albrechts-University of Kiel, subjected to the 1975 Helsinki Declaration. Tissue samples were divided into four subgroups, based on origin, patient past medical history, clinical presentation and histologic diagnosis established by certified pathologists of the University of Schleswig-Holstein, Campus Kiel. The subgroups included 21 hyperplastic palatine tonsils, 25 adenoids, 16 chronic inflammatory palatine tonsils and 27 chronic inflammatory palatine tonsils with histologic signs of acute inflammation as per presence of cryptal ulcerations and leukocyte infiltration. At the time of procedure, the median of age for each subgroup was $6,5,26$, and 7, respectively. Immediately after collection, samples were frozen in liquid nitrogen, and stored at $-80^{\circ} \mathrm{C}$ for further processing.

\section{RNA isolation}

Frozen tissue samples were ground by mortar, and $1 \mathrm{ml}$ of TRIzol $^{\mathrm{TM}}$ reagent (Gibco, Ingolstadt, Germany) was applied upon $200 \mathrm{mg}$ of tissue. Total RNA was isolated following the manufacturer's instructions. After determination of the RNA content using the UVICON-931 UV-spectralphotometer (Kontron, Hamburg, Germany), samples of total RNA were adjusted to $1.0 \mu \mathrm{g}$ for first strand cDNA synthesis. Quality assessment of the RNA was conducted using a $1 \%$ agarose ethidium-bromide stained gel electrophoresis.

\section{Reverse transcription}

$1.0 \mu \mathrm{g}$ RNA was heat-denatured $\left(65^{\circ} \mathrm{C}, 10 \mathrm{~min}\right)$, chilled on ice, and subjected to random hexadeoxynucleotide primed reverse transcription using the first strand cDNA synthesis kit (Pharmacia, Freiburg, Germany). Reverse transcription (final volume $15 \mu \mathrm{l}$ ) was conducted at $37^{\circ} \mathrm{C}$ for $60 \mathrm{~min}$ in the presence of $0.2 \mu \mathrm{M}$ of random hexanucleotide primer and $40 \mathrm{U}$ RNase inhibitor (RNAsin, Gibco, Germany). Following synthesis of the completed first strand cDNA the resulting RNA-cDNA double-stranded helix was heat-denatured $\left(95^{\circ} \mathrm{C}, 5 \mathrm{~min}\right)$ to provide cDNA as a template for polymerisation.

\section{Primers}

We used the following oligonucleotides for high-stringency PCR reaction as listed below. Glutaraldehyde-3-phosphate-dehydrogenase (G3PDH) was used to compare expression of the genes mentioned below:

RANTES sense: 5'-CAT CCT CATT GCT ACT GCC CTC TG-3', RANTES antisense: 5'-TAA CTG CTG CTC GTC GTG GTC-3'; Eotaxin-1 sense: 5'-CAT CCT CAT TGC TAC TGC CCT CTG-3', Eotaxin-1 antisense: 5'-CGG GTT CAC GCC ATT CTC CT-3'; Eotaxin-2 sense: 5'-CAC ATC ATC CCT ACG GGC TCT-3'; Eotaxin-2 antisense: 5'-GGT TGC CAG GAT ATC TCT GGA CAG GG-3'; $M C P-3$ sense: 5'-GAG CTA CAG AAG GAC CAC CAG T-3', $M C P-3$ antisense: 5'-AAG TCC TGG ACC CAC TTC TG-3'; $M C P-4$ sense: 5'-TCA TCT TTC CAC AAT AAC ATA TTT A-3', $M C P-4$ antisense: 5'-GTT TAT TTG AGT ATT GCT GAT CTT T-3'; IL-8 sense: 5'-CTT TCA GAG ACA GCA GAG CAC-3', IL-8 antisense: 5'-ACT GTG AGG TAA GAT GGT GGC-3'; GRO-alpha sense: 5'-TGA ACT GCG CTG CCA GTG C-3', GRO-alpha antisense; G3PDH sense: 5'-CATCCTCATTGCTACTGCCCTCTG-3', G3PDH antisense: 5'ATGAGCCCCAGCCTTCTCCAT-3'. 
Polymerase chain reaction (PCR)

Reverse transcribed cDNA products $(0.25 \mu \mathrm{l})$ were incubated in $50 \mu \mathrm{l}$ reaction mixture containing $0.2 \mu \mathrm{M} 5^{\prime}-3^{\prime}$ ' sequence specific sense oligonucleotide primers, $0.2 \mu \mathrm{M}$ of 3'-5' corresponding antisense oligonucleotide primers, $200 \mu \mathrm{M}$ dNTP's, $1.5 \mathrm{mM} \mathrm{MgCl}, 5.0 \mu \mathrm{l}$ 10x PCR-buffer, and $2.5 \mathrm{U}$ Taq-polymerase (Gibco, Ingolstadt, Germany). The reaction mixture was covered with a mineral oil layer (Applied Biosystem, Weiterstadt, Germany) to prevent evaporation. The PCR was conducted in a Biometra $T_{3}$ thermocycler. Following initial denaturation (3 $\mathrm{min}$ at $\left.95^{\circ} \mathrm{C}\right)$, high stringency PCR was run for 34 cycles $\left(94^{\circ} \mathrm{C}\right.$ for $75 \mathrm{sec}, 60^{\circ} \mathrm{C}$ for $30 \mathrm{sec}$, and $72^{\circ} \mathrm{C}$ for $2 \mathrm{~min}$ ) with an increased annealing temperature of $67^{\circ} \mathrm{C}$ in the first two cycles, to amplify the RANTES, Eotaxin-1, Eotaxin-2 and $G 3 P D H$ cDNA. In case of the other chemokines, the PCR parameters were modified to a 40 cycles of $95^{\circ} \mathrm{C}$ for $60 \mathrm{sec}, 60^{\circ} \mathrm{C}$ for $30 \mathrm{sec}$, and $72^{\circ} \mathrm{C}$ for $2 \mathrm{~min}$, with an increased annealing temperature of $68^{\circ}$ to $60^{\circ}$ over the first 8 cycles. After PCR, all samples were subjected to ethidium-bromide stained $1.5 \%$ agarose gel electrophoresis.

\section{Densitometry}

The amplicons were evaluated in quantity using Herolab E.A.S.Y. Win32 software (Herolab, Wiesloch, Germany). At first, G3PDH bands were compared among each other, in order to assess relative sample signal strength. Subsequently, all other signals of the chemokine bands were adjusted to the relative strength by division through the G3PDH band signal.

\section{Statistical analysis}

All densitometric data obtained from the SQRT-PCR were analysed using SPSS 9.0 (Statistical Package for the Social Sciences, SPSS Inc., Chicago, IL, USA). All data assembled in this study were tested for normal distribution using the Kolmogoroff-Smirnov test. Expression profiles of each chemokine were analysed among each group using simple block variance analysis and Kruskal-Wallis test for normally and non-normally distributed data, respectively. A p-value $<0.05$ was considered significant, and a $p$-value $<0.01$ was considered highly significant.

\section{Results}

Quality assessment of the isolated RNA was made by agarose gel electrophoresis exhibiting non-fragmented RNA with sufficient quantity for reverse transcription and subsequent processing. After RT-PCR procedures, samples were processed by agarose gel electrophoresis, and the amplicons of the chemokines were measured and adjusted to the relative G3PDH signal strength, comparative anal- ysis was initiated. All data followed normal distribution and are displayed as mean \pm SD in the following.

Four cohorts were examined: patients with tonsillar hyperplasia $(n=21)$, adenoids $(n=25)$, chronic tonsillitis $(\mathrm{n}=16)$ and chronic tonsillitis with histological proof of acute inflammation (further in the text referred to as "acute tonsillitis") $(\mathrm{n}=27)$.

\section{RANTES and Eotaxin}

Relative RANTES total-mRNA expression showed a median of 1.37 for tonsil hyperplasia 1.58 for adenoids, 1.32 for chronic tonsillitis and 1.56 for acute tonsillitis (Table I, Fig. 1A). As shown in Table II and Fig. 1B, relative mRNA expression for eotaxin-2 was 1.02 in tonsillar hyperplasia (median value), 1.34 for adenoids, 1.16 for chronic tonsillitis and 1.16 for acute tonsillitis. A significant overexpression of eotaxin- 2 was observed in adenoids compared to patients with chronic tonsillitis $(\mathrm{p}<0.05)$.

\section{IL-8 and GRO-alpha}

Relative expression of IL- 8 are shown in Table III and Figure 2A. A relative IL-8-mRNA expression was found to be a median of 1.12 in tonsillar hyperplasia, 1.97 for adenoids, 1.82 for chronic tonsillitis and 1.41 for acute tonsillitis. IL-8 was significantly overexpressed in patients with chronic inflammatory tonsillar disease (with and without acute inflammation) compared to tonsil hyperplasia. Relative GRO-alpha mRNA expression levels are shown in Table IV and Figure 2B. Median values were 0.84 for tonsillar hyperplasia, 1.07 for adenoids, 0.60 for chronic tonsillitis and 0.55 for acute tonsillits.

All other examined cytokines were not significantly expressed in the groups analysed.

\section{Discussion}

Waldeyer's tonsillar ring acts as the first line of immune defence against microbes, entering the body nasally or orally. Especially in children, the immunogenic properties of the palatine tonsils are of particular importance. Chemokines are small signalling proteins, whose expression in various tissues is variably regulated during immune responses as well as acute and chronic infection. Previous studies have suggested a functional role for chemokines in hepatitis, colitis, pancreatitis, asthma and various malignancies as well as acute and chronic infections of the upper aerodigestive tract ${ }^{18-23}$. Most chemokines are only produced and secreted upon appropriate stimulation of cells by bacterial or viral products ${ }^{24}$. In cases of acute and chronically infected tonsils, accumulation of certain subsets of chemokines and neutrophilic dynamics has been observed ${ }^{25}$. 
Table I. Relative expression of total RNA for RANTES. A total of 89 tissue samples were analysed.

\begin{tabular}{lcccc} 
& $\begin{array}{c}\text { Tonsillar } \\
\text { hyperplasia } \\
(\mathbf{n}=\mathbf{2 1})\end{array}$ & $\begin{array}{c}\text { Adenoids } \\
(\mathbf{n}=\mathbf{2 5})\end{array}$ & $\begin{array}{c}\text { Chronic } \\
\text { tonsillitis } \\
\mathbf{( n = 1 6 )}\end{array}$ & $\begin{array}{c}\text { Acute } \\
\text { tonsillitis } \\
\mathbf{( n = 2 7 )}\end{array}$ \\
Minimum & 0,41 & 0.00 & 0.54 & 0.00 \\
1. Quartile & 1.07 & 1.34 & 0.97 & 1.15 \\
Median & 1.37 & 1.58 & 1.32 & 1.56 \\
3. Quartile & 1.79 & 2.11 & 1.45 & 1.97 \\
Maximum & 5.57 & 2.46 & 1.95 & 2.46 \\
\hline
\end{tabular}

A

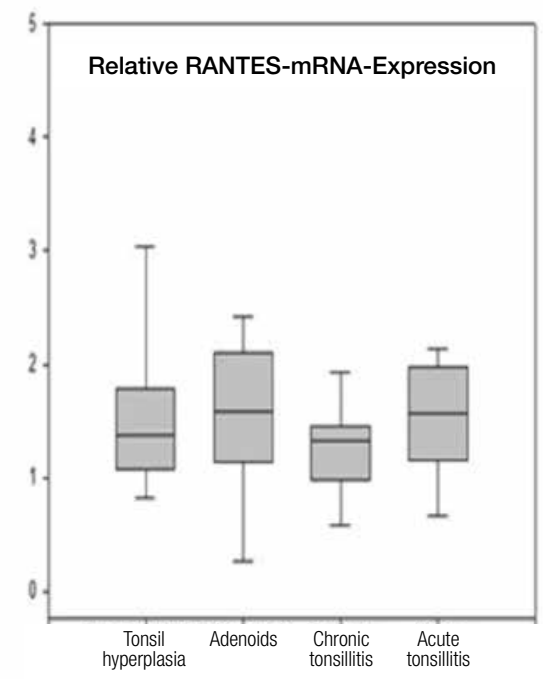

B

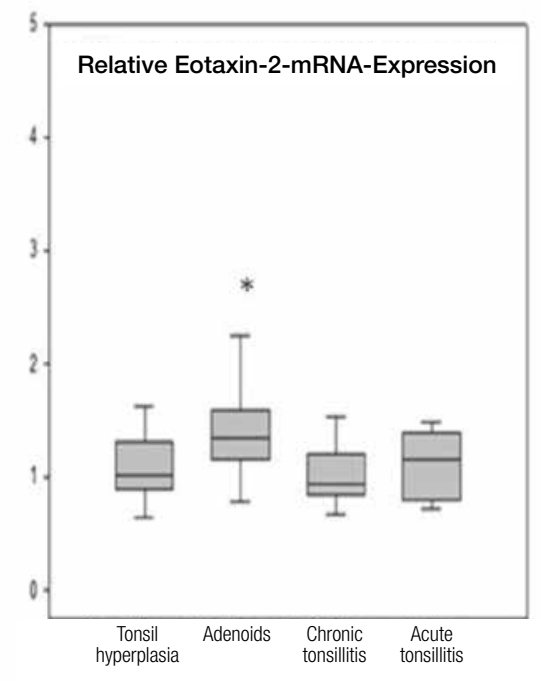

Fig. 1. (A) Relative expression of total RNA for RANTES. (B) Relative expression of total RNA for eotaxin-2. Expression was correlated to the expression of the housekeeping gene G3PDH in each sample. The plots represent 89 tissue samples. ${ }^{\star} p<0.05 .{ }^{\star \star} p<0.01$.
Table II. Relative expression of total RNA for Eotaxin-2. A total of 89 tissue samples were analysed.

\begin{tabular}{lcccc} 
& $\begin{array}{c}\text { Tonsillar } \\
\text { Hyperplasia } \\
(\mathbf{n}=\mathbf{2 1})\end{array}$ & $\begin{array}{c}\text { Adenoids } \\
(\mathbf{n}=\mathbf{2 5})\end{array}$ & $\begin{array}{c}\text { Chronic } \\
\text { tonsillitis } \\
\mathbf{( n = 1 6 )}\end{array}$ & $\begin{array}{c}\text { Acute } \\
\text { tonsillitis } \\
(\mathbf{n}=\mathbf{2 7})\end{array}$ \\
Minimum & 0.55 & 0.40 & 0.63 & 0.30 \\
1. Quartile & 0.89 & 1.16 & 0.84 & 0.80 \\
Median & 1.02 & 1.34 & 0.95 & 1.16 \\
3. Quartile & 1.31 & 1.60 & 1.21 & 2.14 \\
Maximum & 3.83 & 2.50 & 1.82 & 2.86 \\
\hline
\end{tabular}

A

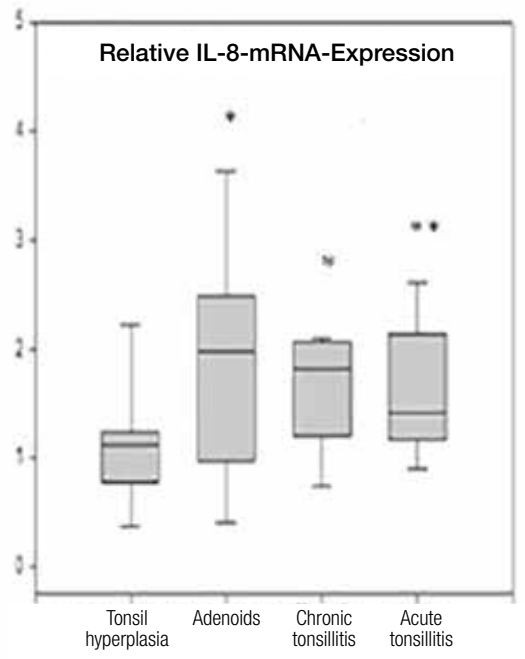

B

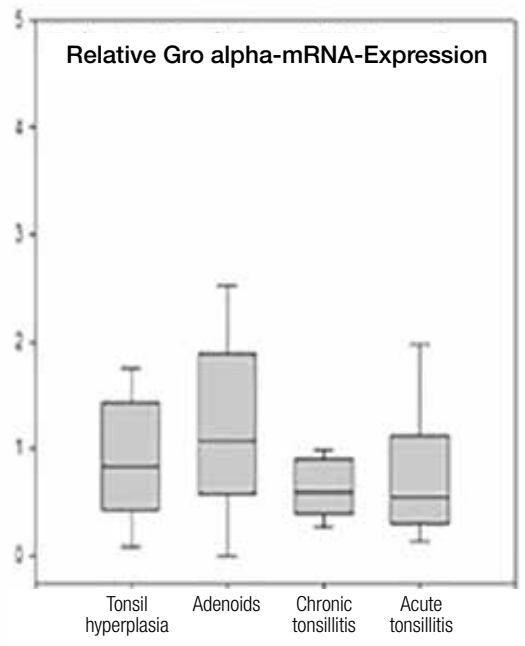

Fig. 2. (A) Relative expression of total RNA for IL-8. (B) Relative expression of total RNA for gro-alpha. Expression was correlated to the expression of the housekeeping gene G3PDH in each sample. The plots represent 89 tissue samples. ${ }^{\star} p<0.05$. ${ }^{\star \star} p<0.01$. 
Table III. Relative expression of total RNA for IL-8. A total of 89 tissue samples were analysed.

\begin{tabular}{lcccc} 
& $\begin{array}{c}\text { Tonsillar } \\
\text { hyperplasia } \\
(\mathbf{n = 2 1 )}\end{array}$ & $\begin{array}{c}\text { Adenoids } \\
(\mathbf{n}=25)\end{array}$ & $\begin{array}{c}\text { Chronic } \\
\text { tonsillitis } \\
\mathbf{( n = 1 6 )}\end{array}$ & $\begin{array}{c}\text { Acute } \\
\text { tonsillitis } \\
\mathbf{( n = 2 7 )}\end{array}$ \\
Minimum & 0.13 & 0.27 & 0.61 & 0.52 \\
1. Quartile & 0.78 & 0.98 & 1.20 & 1.17 \\
Median & 1.12 & 1.97 & 1.82 & 1.41 \\
3. Quartile & 1.24 & 2.50 & 2.06 & 2.14 \\
Maximum & 2.55 & 4.98 & 2.90 & 2.86 \\
\hline
\end{tabular}

IL-8 has been described to be very potent in neutrophil activation and migration ${ }^{26}{ }^{27}$. Our data shows significant overexpression of IL-8 in chronic inflammatory tonsillar disease. Since IL- 8 expression has been reported to be effectively stimulated by TNF- $\alpha$ und IL- $1 \beta$ for neutrophil chemotaxis as well as activity, our data suggests that a Th1 response is predominatly involved in the pathogenesis of chronic tonsillitis.

Both IL- 8 and GRO- $\alpha$ are known to be synthesised by neutrophils and fibroblasts in response to various stimu$\mathrm{li}^{2829}$. In vitro, IL- $1 \beta$ and TNF- $\alpha$ seem to be potent stimulators of chemokine production, whereas IFN- $\gamma$ inhibits their production ${ }^{18}$. GRO-alpha is further produced by endothelial cells, fibroblasts and monocytes after stimulation with lipopolysaccharide, IL-1 or TNF- $\alpha$ in vitro. In addition, it induces neutrophil accumulation and chemotaxis ${ }^{29}$. In our data however, GRO-alpha was not significantly overexpressed in chronic tonsillar diseases.

Tonsillar hyperplasia appears to be a result of increased proliferation of lymphoid tissue predominantly triggered by bacterial infections. Previously, tonsil size has been shown to be directly proportional to the mean bacterial load ${ }^{30}$. The kind of bacteria found in hyperplastic tonsils does not seem to greatly differ from those in recurrently active infected tonsils. However, Haemophilus infection, besides Staphylococcus aureus and Streptococcus pyogenes appears to be more common in tonsillar hyperplasia ${ }^{30}$. Our investigations demonstrate that hyperplastic tonsillitis is characterised by an acute inflammatory chemokine pattern as IL-8 expression on mRNA levels correlates with the presence of actively infected tissue. IL-8 expression was significantly elevated in acutely infected tissue compared to hyperplastic tonsils $(\mathrm{p}<0.01)$, and in adenoids and chronic tonsillitis compared to hyperplastic tonsils ( $\mathrm{p}$ $<0.05$ ). Therefore, as IL-8 is an acute phase chemokine expressed in chronic tonsillitis, this suggests an inflammatory process in the pathogenesis of chronic tonsillitis. An elevation of IL-8 in acute infections has been described previously ${ }^{31} 32$, and therefore anticipated for tonsillar dis-
Table IV. Relative expression of total RNA for Gro-alpha. A total of 89 tissue samples were analysed.

\begin{tabular}{lcccc} 
& $\begin{array}{c}\text { Tonsillar } \\
\text { hyperplasia } \\
(\mathbf{n = 2 1 )}\end{array}$ & $\begin{array}{c}\text { Adenoids } \\
(\mathbf{n}=\mathbf{2 5})\end{array}$ & $\begin{array}{c}\text { Chronic } \\
\text { tonsillitis } \\
\mathbf{( n = 1 6 )}\end{array}$ & $\begin{array}{c}\text { Acute } \\
\text { tonsillitis } \\
(\mathbf{n}=\mathbf{2 7})\end{array}$ \\
Minimum & 0.00 & 0.00 & 0.00 & 0.00 \\
1. Quartile & 0.43 & 0.59 & 0.40 & 0.30 \\
Median & 0.84 & 1.07 & 0.60 & 0.55 \\
3. Quartile & 1.43 & 1.90 & 0.91 & 1.12 \\
Maximum & 2.44 & 3.33 & 1.28 & 2.97 \\
\hline
\end{tabular}

ease. However there have been studies showing an equal expression of IL-8 in hyperplastic tonsils and chronic tonsillitis ${ }^{33}$. Another reason for a high expression of this chemokine in chronic and hyperplastic disease could be its additional extensive effect on cell proliferation ${ }^{34}$.

A similar result would have been expected for the expression of GRO-alpha, since this chemokine also plays an important role in host immune defence by conveying chemotaxis and activation of neutrophils, similar to IL-8. However, in our data, mRNA expression levels of GROalpha were not significantly elevated in acute nor chronic tonsillitis compared to tonsillar hyperplasia.

MCP 1-4, RANTES, eotaxin, eotaxin-2 und eotaxin-3 are CC-chemokines. RANTES is a selective attractant for T-cell and monocytes migration ${ }^{35}$. Proinflammatory cytokines, such as TNF- $\alpha$ or IL-1ß, have been described to be some of the most potent stimulators of RANTES expression. Furthermore, a combination of TNF- $\alpha$ and INF$\chi$ strongly stimulate production of RANTES ${ }^{36}$. Another important function of RANTES is its ability to enhance the mucosal as well as systemic humoral production of antibodies, via an elevation of the production of IFN- $\chi-$, IL-2-, IL-5-and IL-6, and further an induction of co-stimulatory molecules as well as expression of cytokine receptors for CD $4^{+} \mathrm{T}$ cells ${ }^{37}$.

In our data, RANTES expression was evident in all subgroups analysed with no significant differences in relative mRNA expression levels within these groups.

Eotaxin-2 is also described to be a potent chemoattractor for eosinophils in vitro and in vivo ${ }^{3839}$. In eosinophils, eotaxin- 2 causes a dose-dependent increase of the production of free radicals, mobilisation of intracellular calcium and upregulation of CD11b ${ }^{40}$.

Eotaxin-2 expression was evident in all analysed subgroups with a significant upregulation in adenoids, suggesting an involvement of Th2- immune responses as eotaxin-2 which is known to play a crucial role in the pathogenesis of atopic diseases involving Th 2- cell activation ${ }^{41}$. Significant upregulation of eotaxin-2 has been 
observed in bronchial asthma ${ }^{42}$ and allergic rhinitis ${ }^{43}$. However, the significance of eotaxin-2 expression in lymphatic tissue of the Waldeyer's tonsillar ring still largely remains uncertain, like their role in the maturation of the adaptive immune system in the mucosa of the upper aerodigestive tract. However, it is remarkable that eotaxin-2 as well as RANTES are constitutively expressed in the mucosa of the gastrointestinal tract, an organ with distinctive antigen contact, such as Waldeyer's tonsilar ring ${ }^{44} 45$. To further evaluate the role of the chemokines analysed in the function of the lymphatic tissue of the Waldeyer's tonsillar ring, it is essential to evaluate their expression on protein level to examine alterations through potential post-transcriptional splicing. Also, immunohistochemical studies would be of interest to evaluate their expression in relation to certain cell populations. These studies would greatly aid in understanding the pathophysiology of tonsillar disease, from which patients could benefit in the future.

\section{Conclusions}

The presented data suggest that the majority of diseases related to adenoid formation are mediated via an eotaxin-2 expression, whereas chronic inflammatory tonsillitis is associated with IL-8 upregulation. Thus, these data imply that adenoids are related to a Th-2 response, and chronic inflammatory tonsillitis to a Th- 1 based immune response.

\section{References}

1 Waldeyer W. Wie soll man Anatomie lehren und lernen? Dtsch Med Wochenschr; 1884. p. 313.

2 Siegel G. Theoretical and clinical aspects of the tonsillar function. Int J Pediatr Otorhinolaryngol 1983;6:61-75.

3 Slipka J, Slipka J Jr. The palatine tonsil as an evolutionary novelty. Acta Otolaryngol 1996; 523:8-11.

4 Bykova V. Morphofunctional organization of the palatine tonsils as a lymphoepithelial organ. Vestn Otorinolaringol 1998;1:41-5.

5 Dono M, Zupo S, Colombo M, et al. The human marginal zone B cell. Ann N Y Acad Sci 2003;987:117-24.

6 Horter D, Yoon KJ, Zimmerman JJ. A review of porcine tonsils in immunity and disease. Anim Health Res Rev 2003;4:143-55.

7 Perry M, Whyte A. Immunology of the tonsils. Immunol Today 1998;19:414-21.

8 Zautner AE. Adenotonsilar disease. Recent Pat Inflamm Allergy Drug Discov 2012;6:121-9.

9 Wong D, Ogra PL. Immunology of tonsils and adenoids-an update. Int J Pediatr Otorhinolaryngol 1980;2:181-91.

10 Richardson M. Sore throat, tonsillitis, and adenoiditis. Med Clin North Am 1999;83:75-83.
11 Luster A. Chemokines--chemotactic cytokines that mediate inflammation. N Engl J Med 1998;338:436-45.

12 Ono S, Nakamura T, Miyazaki D, et al. Chemokines: roles in leukocyte development, trafficking, and effector function. J Allergy Clin Immunol 2003;111:1185-99.

13 Ryu JH, Park M, Kim BK, et al. Tonsil-derived mesenchymal stromal cells produce CXCR2-binding chemokines and acquire follicular dendritic cell-like phenotypes under TLR3 stimulation. Cytokine 2015;73:225-35.

14 Liang Y, Hasturk H, Elliot J, et al. Toll-like receptor 2 induces mucosal homing receptor expression and IgA production by human B cells. Clin Immunol 2011;138:33-40.

15 Teran L, Davies DE. The chemokines: their potential role in allergic inflammation. Clin And Exp Allergy 1996;26:1005-19.

16 Adams D, Lloyd AR. Chemokines: leukocyte recruitment and activation cytokines. Lancet 1997;349:490-6.

17 Matthews A, Friend DS, Zimmermann N, et al. Eotaxin is required for the baseline level of tissue eosinophils. Proc Natl Acad Sci USA 1998;65:6273.

18 Fahey S, Dempsey E, Long A. The role of chemokines in acute and chronic hepatitis $C$ infection. Cell Mol Immunol 2014;11:25-40.

19 Yamamoto-Furusho JK, Ascaño-Gutiérrez I, Furuzawa-Carballeda J, et al. Differential expression of MUC12, MUC16, and MUC20 in patients with active and remission ulcerative colitis. Mediators Inflamm 2015:659018.

20 Binker MG, Cosen-Binker LI. Acute pancreatitis: the stress factor. World J Gastroenterol 2014;21:5801-7.

21 Corrales L, Matson V, Flood B, et al. Innate immune signaling and regulation in cancer immunotherapy. Cell Res 2017;27:96-108.

22 Zeng R, Li C, Li N, et al. The role of cytokines and chemokines in severe respiratory syncytial virus infection and subsequent asthma. Cytokine 2011;53:1-7.

23 Meyer JE, Beier UH, Görögh T, et al. Defensin and chemokine expression patterns in the palatine tonsil: a model of their local interaction. Eur Arch Otorhinolaryngol 2006;263:319-26.

24. Marshall JS, King CA, McCurdy JD. Mast cell cytokine and chemokine responses to bacterial and viral infection. Curr Pharm Des 2003;9:11-24.

25 Brandtzaeg P. Function of mucosa-associated lymphoid tissue in antibody formation. Immunol Invest 2010;39:303-55.

26 Hosoki K, Itazawa T, Boldogh I, et al. Neutrophil recruitment by allergens contribute to allergic sensitization and allergic inflammation. Curr Opin Allergy Clin Immunol 2016;16:45-50.

27 Palomino DC, Marti LC. Chemokines and immunity. Einstein 2015;13:469-73.

28 David JM, Dominguez C, Hamilton DH, et al. The $I L-8 / I L$ $8 R$ axis: a double agent in tumor immune resistance. Vaccines (Basel) 2016;4.

29 Miller MD, Krangel MS. Biology and biochemistry of the chemokines: a family of chemotactic and inflammatory cytokines. Crit Rev Immunol 1992;12:17-46. 
30 Brodsky L, Moore L, Stanievich JF, et al. The immunology of tonsils in children: the effect of bacterial load on the presence of B-and T-cell subsets. Laryngoscope 1988;98:93-8.

31 Macdonald SP, Stone SF, Neil CL, et al. Sustained elevation of resistin, NGAL and $I L-8$ are associated with severe sepsis/septic shock in the emergency department. PLoS One 2014;24:9:e110678.

32 Sheng WH, Chiang BL, Chang SC, et al. Clinical manifestations and inflammatory cytokine responses in patients with severe acute respiratory syndrome. J Formos Med Assoc 2005;104:715-23.

33 Agren K, Andersson U, Litton M, et al. The production of immunoregulatory cytokines is localized to the extrafollicular area of human tonsils. Acta Otolaryngol 1996;116:477-85.

34. Li J, Thornhill MH. Growth-regulated peptide-alpha (GROalpha) production by oral keratinocytes: a comparison with skin keratinocytes. Cytokine 2000;12:1409-13.

35 Lukacs NW. Migration of helper T-lymphocyte subsets into inflamed tissues. J Allergy Clin Immunol 2000;106:264-9.

36 Qidwai T. Chemokine genetic polymorphism in human health and disease. Immunol Lett 2016;176:128-38.

37. Lillard JW Jr, Boyaka PN, Taub DD, et al. RANTES potentiates antigen-specific mucosal immune responses. J Immunol 2001;166:162-9.
38 Perretti M. Lipocortin 1 and chemokine modulation of granulocyte and monocyte accumulation in experimental inflammation. Gen Pharmacol 1998;31:545-52.

39 Pawankar R. Nasal polyposis: an update: editorial review. Curr Opin Allergy Clin Immunol 2003;3:1-6.

40 Medoff BD, Seung E, Hong S, et al. CD11b+ myeloid cells are the key mediators of Th2 cell homing into the airway in allergic inflammation. J Immunol 2009;182:623-35.

41 Pivarcsi A, Homey B. Chemokine networks in atopic dermatitis: traffic signals of disease. Curr Allergy Asthma Rep 2005;5:284-90.

42 Sampson AP. The role of eosinophils and neutrophils in inflammation. Clin Exp Allergy 2000;30:22-7.

43 Samivel R, Kim EH, Chung YJ, et al. Immunomodulatory effect of tonsil-derived mesenchymal stem cells in a mouse model of allergic rhinitis. Am J Rhinol Allergy 2015;29:262-7.

44 Adar T, Grisaru-Granovsky S, Ben Ya'acov A, et al. Pregnancy and the immune system: general overview and the gastroenterological perspective. Dig Dis Sci 2015;60:2581-9.

45 Günaltay S, Kumawat AK, Nyhlin N, et al. Enhanced levels of chemokines and their receptors in the colon of microscopic colitis patients indicate mixed immune cell recruitment. Mediators Inflamm 2015;2015:132458. 